\title{
ASSOCIATION BETWEEN FINGERPRINT PATTERNS AND MYOPIA
}

\section{LJILJANA SRETIĆ ${ }^{1}$}

${ }^{1}$ Faculty of Science and Mathematics, University of Priština, Kosovska Mitrovica, Serbia

\begin{abstract}
Epidermal patterns are polygenically determined system of ridges on volar surface of fingers, palms and soles. Due to their mode of inheritance, and developmental time that coincide with the most critical period of embryogenesis, they are considered as a biological marker that may provide an insight in early fetal life. This study involved 102 participants, students from the University of Priština-Kosovska Mitrovica, 51 consisting myopic and 51 control group. Analysis of fingerprint patterns has showed significantly altered dermatoglyphic configuration of arch patterns in myopic group, which might be suggestive of developmental perturbances in embryogenesis of genetically vulnerable individuals prone to development of myopia.
\end{abstract}

Keywords: Epidermal patterns, Myopia, Arches.

\section{INTRODUCTION}

Fingerprint patterns, designated also as dermatoglyphics, are epidermal ridge configurations on fingers, palms, soles and toes. Although the other primates have ridges on the ventral surface of the palms and soles, the rich variety of dermal ridge patterns is unique for humans (Cummins \& Midlo, 1976). Fingerprint development starts in the most sensitive period of fetal life, with the appearance of local temporary eminencesvolar pads, as early as $6^{\text {th }}$ gestational week. Once formed they remain permanent throughout lifetime.

Dermatoglyphic phenotype is considered to be a result of an interrelationship between genetic and environmental factors (Bouchard et al., 1990; Arrieta et al., 1992). Their high heritability has been demonstrated in the studies of monozygotic twins, reaching for some dermatoglyphic features, such as arch patterns or finger ridge count, heritability of $91 \%$, i.e $95 \%$ or more (Holt, 1968; Bokhari et al., 2002; Reed et al., 2006; Machado et al., 2010). There is a wide agreement that inheritance of most dermatoglyphic features conforms to polygenic system (Holt, 1968; Chakraborty, 1991; Ismail et al., 2009; Karmakar \& Kobyliansky, 2011). Since that dermatoglyphic patterns morphology depends on volar pads shape and size it is postulated that these genes affect epidermal ridge formation indirectly, through growth rate, timing events, skeletal factors, vascularization and innervation of dermis and other ontogenic factors (Wertheim \& Maceo, 2002; Todd et al., 2006). In a study conducted by Nousbeck et al. SMARCADI has been suggested as a possible genetic factor that might regulate dermatoglyphic morphogenesis. SMARCAD1, located at $4 \mathrm{q} 22$, is a gene that encodes a protein structurally related to SWI2/SNF2 superfamily of ATP dependant ATPases, which are catalytic subunits of chromatin remodeling complexes, considered as major regulators of transcriptional activity (Adra et al., 2000). A

\footnotetext{
*Corresponding author: 1sretic@gmail.com BIOLOGY
}

short isoform of SMARCADI gene is exclusively expressed in the skin. A mutation, that likely exerts loss-of-function effect, disrupting conserved donor splice site adjacent to $3^{\prime}$ end of noncoding exon uniquely present in skin-specific short isoform of a gene, is found in condition known as adermoglyphia, thus indicating its possible role in friction ridge ontogenesis (Nousbeck et al., 2011). Genom wide association study of Ho et al. (2016), which tried to elucidate a genetic match with respect to the presence or absence of whorl patterns, found that the most of SNPs polymorphisms variants within ADAMTS9-AS2 appear to be associated with whorl patterns incidence on all digits, at different levels of significance. Significant results were also found in an intergenic region on chromosome 12, near $T B X 3$ and $M E D 113 L$ genes and a variant within $O L A 1$ gene, but the finding for ADAMTS9-AS2 were more concrete. ADAMTS9-AS2 is tumor suppressor widely expressed in fetal tissues. Its product is an antisense RNA involved in chromatin remodeling and transcriptional/posttranscriptional regulation, but also serve as a precursor of siRNA, pointing to an epigenetic regulation in fingerprint formation.

Dermatoglyphics are phylogenetically more stable than other biological traits, and appear to be evolutionary conservative, which renders them more reliable for studies of the historical relationships of populations (Froehlich \& Giles, 1981). Besides, mode of inheritance and morphogenesis in early fetal life make them a sensitive indicator of intrauterine disruptions of genetic and/or environmental origin (Martin et al., 2004). Deviant dermatoglyphic configurations have been found in numerous chromosomal and multifactorial disorders (Martin et al., 2004; Cam et al., 2008; Mital et al., 2012; Stošljević \& Adamović, 2013; Gradiser et al., 2016).

Development of an eye is genetically determined process (Gehring, 2002). Structural changes in eye components are strongly associated with myopia, leading to blurred vision of distant objects. It is a complex disorder influenced by both genetic and environmental factors (Tang et al., 2008). Evidences 
of myopia heritability stem from the studies of familial clustering (Guggenheim et al., 2000), high reccurence risk in offspring (Farbrother et al., 2004) and heritability values in twins (Sanfilippo et al., 2010). Numerous genes that have been proposed as candidate genes in etiology of myopia are found to regulate neuronal development, neurotransmission, signaling, remodeling of extracellular matrix, retinoic acid metabolism and apoptosis (Li \& Zhang, 2017).

Since that ocular components and skin share common ectodermal origin and developmental time, we hypothesized that deviant dermatoglyphic composition, due to the pleiotropic effect of the genes involved in oculogenesis, may indicate the dysmorphogenesis of the ectodermal tissue and its derivates. The aim of this study was to evaluate effect of myopic disorder on dermatoglyphic patterns, as a morphological biomarker that might provide a clue of genetic susceptibility to myopia, as well as a time window of intrauterine perturbancies.

\section{MATERIAL AND METHODS}

Research sample comprised 102 students of the University of Priština-Kosovska Mitrovica, 51 myopic individuals and 51 healthy controls. They were, according to sex and vision, split into four groups: control males $(\mathrm{N}=25)$, control females $(\mathrm{N}=26)$, myopic males $(\mathrm{N}=25)$ and myopic females $(\mathrm{N}=26)$. Fingerprints, provided by ink and paper method (Cummins \& Midlo, 1976), were scanned (CannonScanLIDE 25) and processed by program for image editing (Adobe Photoshop CS3). Dermatoglyphic patterns were classified as arch (A), loops (L) and whorls (W) (Galton, 2004). They are differentiated according to landmark structures-triradius, a point from which three ridge systems course in three different directions at angles of about $120^{\circ}$, and a core point referring to the center of the pattern. Arches are the simplest pattern with no triradius, formed by succession of more or less parallel ridges which traverse the pattern area and form a curve that is concave proximaly. Loops have one triradius and consist of series of ridges entering pattern area on one side, recurving and exiting from the same side. They are designated as radial, if the loop ridges open toward thumb (RL), and ulnar, if the ridges open toward little finger (UL). Whorl patterns, with two triradii, have ridges arranged as circles, ellipses or spirals around the core of the pattern. Comparisons of patterns distribution between groups were made using chi-square test, with $\mathrm{p}$ value less than 0.05 considered as the minimum level of significance. The study provided written informed consent from each participant.

\section{RESULTS}

Table 1 presents patterns distribution, both hands pooled together, in males and females from control and myopic group. Significant sex differences have been noted for whorl and arch paterns in myopic group, being highly significant for arch patterns, but as for whorls significance was recorded in control group as well.

Table 1. Patterns distribution on both hands in control and myopic group.

\begin{tabular}{|l|c|c|c|c|c|}
\hline \multicolumn{5}{|c|}{ Pattern type N (\%) } \\
\hline Group & Sex & A & UL & RL & W \\
\hline Control & Males & $11(4.4)$ & $123(49.2)$ & $6(2.4)$ & $110(44)$ \\
& Females & $7(2.8)$ & $152(60.8)$ & $9(3.6)$ & $82(32.8)$ \\
& $\chi^{2}$ & 0.889 & 3.058 & 0.6 & 4.083 \\
& $\mathrm{p}$ & 0.346 & 0.08 & 0.439 & 0.043 \\
\hline Myopic & Males & $2(0.80)$ & $135(54.22)$ & $10(4.02)$ & $102(40.96)$ \\
& Females & $20(7.69)$ & $156(60.00)$ & $10(3.85)$ & $74(28.46)$ \\
& $\chi^{2}$ & 14.727 & 1.515 & 0.000 & 4.455 \\
& $\mathrm{p}$ & 0.000 & 0.218 & 1.000 & 0.035 \\
\hline
\end{tabular}

Comparison within the same sex also revealed significance for arch patterns, due to the low frequency in myopic males in relation to control males, and high frequency in myopic females in relation to control females (Table 2).

Table 2. Patterns distribution on both hands in males and females.

\begin{tabular}{|l|c|c|c|c|c|}
\hline \multicolumn{6}{|c|}{ Pattern type N $(\%)$} \\
\hline Group & Sex & A & UL & RL & W \\
\hline Males & Control & $11(4.4)$ & $123(49.2)$ & $6(2.4)$ & $110(44)$ \\
& Myopic & $2(0.80)$ & $135(54.22)$ & $10(4.02)$ & $102(40.96)$ \\
& $\chi^{2}$ & 6.231 & 0.558 & 1.000 & 0.302 \\
& $\mathrm{p}$ & 0.013 & 0.455 & 0.317 & 0.583 \\
\hline Females & Control & $7(2.8)$ & $152(60.8)$ & $9(3.6)$ & $82(32.8)$ \\
& Myopic & $20(7.69)$ & $156(60.00)$ & $10(3.85)$ & $74(28.46)$ \\
& $\chi^{2}$ & 6.259 & 0.052 & 0.053 & 0.410 \\
& $\mathrm{p}$ & 0.012 & 0.820 & 0.819 & 0.522 \\
\hline
\end{tabular}

Table 3. Patterns distribution on individual hands in males.

\begin{tabular}{|l|c|c|c|c|c|c|c|c|}
\hline \multirow{9}{*}{ Hand } & \multicolumn{9}{c}{ Control } \\
\multicolumn{1}{|c|}{ Pattern type N (\%) } \\
\hline & $\mathrm{A}$ & $\mathrm{UL}$ & $\mathrm{RL}$ & $\mathrm{W}$ & $\mathrm{A}$ & $\mathrm{UL}$ & $\mathrm{RL}$ & $\mathrm{W}$ \\
\hline $\mathrm{L}$ & $6(4.8)$ & $64(51.2)$ & $4(3.2)$ & $51(40.8)$ & $2(1.61)$ & $82(66.13)$ & $5(4.03)$ & $35(28.23)$ \\
$\mathrm{R}$ & $5(4.0)$ & $59(47.2)$ & $2(1.6)$ & $59(47.2)$ & $0(0.0)$ & $53(42.4)$ & $5(4.0)$ & $67(53.6)$ \\
$\chi^{2}$ & 0.0 & 0.25 & 0.17 & 0.79 & 0.51 & 13.18 & 0.09 & 15.54 \\
$\mathrm{p}$ & 1.0 & 0.61 & 0.67 & 0.37 & 0.47 & 0.001 & 0.75 & 0.001 \\
\hline
\end{tabular}


Table 4. Patterns distribution on individual hands in females.

\begin{tabular}{|c|c|c|c|c|c|c|c|c|}
\hline \multirow[t]{2}{*}{ Hand } & \multicolumn{4}{|c|}{$\begin{array}{c}\text { Control } \\
\text { Pattern type } \mathrm{N}(\%)\end{array}$} & \multicolumn{4}{|c|}{$\begin{array}{c}\text { Myopia } \\
\text { Pattern type } \mathrm{N}(\%)\end{array}$} \\
\hline & $\mathrm{A}$ & UL & RL & $\mathrm{W}$ & $\mathrm{A}$ & UL & RL & $\mathrm{W}$ \\
\hline $\mathrm{L}$ & $4(3.2)$ & $77(61.6)$ & $4(3.2)$ & $40(32.0)$ & 11(8.46) & $72(55.38)$ & $5(4.03)$ & $39(30.0)$ \\
\hline $\mathrm{R}$ & $3(2.4)$ & $75(60.0)$ & $5(4.0)$ & $42(33.6)$ & $9(6.92)$ & $84(64.62)$ & $5(4.0)$ & $35(26.92)$ \\
\hline$\chi^{2}$ & 0.0 & 0.01 & 0.0 & 0.01 & 0.05 & 1.93 & 2.60 & 0.17 \\
\hline $\mathrm{p}$ & 1.0 & 0.89 & 1.0 & 0.89 & 0.81 & 0.16 & 0.10 & 0.68 \\
\hline
\end{tabular}

Patterns distribution on the left and right hand of control and myopic males and females are displayed in Tables 3 and 4. The only significance was observed in myopic males who have more ulnar loops on the left and whorls on the right hand.

\section{DISCUSSION}

Myopia, or nearsightedness, is the most common human multifactorial eye disorder in the world, with a prevalence of an increasing tendency, so that there is a prediction that $49.8 \%$ of the world population will be with myopia and $9.8 \%$ with high myopia by 2050 (Holden et al., 2016).

The main limitation of this study was very sparse literature and reliable data referring dermatoglyphic characteristics in myopia, which considerably has reduced adequate comparison. The most striking finding of our study concerns arch patterns, significantly decreased in myopic males, which is in accordance with a previous work of Chaterjee (1991), and increased in myopic females. Morphogensesis of dermatoglyphic patterns depends on size and shape of volar pads that are genetically predetermined. Adverse intrauterine influences might disturb timing of volar pad regression and ridge differentiation. These abnormalities in growth process are liable to distort the alignment of dermal ridges (Ashbaugh, 1992; Babler, 1991; Wertheim \& Maceo, 2002), leading to arch formation in the case of earlier volar pad regression (Meier, 1987). Since that difference in whorl patterns are found between males and females in both control and myopic group, it appears that it stems from sexual dimorphism found in general population. Sexual dimorphism may be under certain environmental influences, especially among males as a more sensitive during prenatal period (Kobyliansky \& Micle, 1987). Differences in pattern distributions between hands were found to be significant only in myopic males. This might be due to the relatively unstable genetic control in myopic males during embryogenesis, since that, in general, one of the major indicator of developmental instability is presence of asymmetry between normally symmetric bilateral traits (Adams \& Niswander, 1967; Naugler \& Ludman, 1996).

\section{CONCLUSION}

The results of our studies confirmed altered dermatoglyphic configuration in myopic individuals, which might indicate developmental perturbances in early embryogenesis of genetically vulnerable individuals. Although suggestive they could not stand per se for dermatoglyphic marker of myopia. In order to establish more informative conclusion further investigation should incorporate quantitative parameters and a level of fluctuating asymmetry.

\section{REFERENCES}

Adams, M. S., \& Niswander, J. D. 1967. Developmental 'Noise' and a congenital malformation. Genetical Research, 10(03), p. 313. doi:10.1017/s0016672300011071

Adra, C. N., Donato, J., Badovinac, R., Syed, F., Kheraj, R., Cai, H., . . . Drews, R. 2000. SMARCAD1, a Novel Human Helicase Family-Defining Member Associated with Genetic Instability: Cloning, Expression, and Mapping to 4q22-q23, a Band Rich in Breakpoints and Deletion Mutants Involved in Several Human Diseases. Genomics, 69(2), pp. 162-173. doi:10.1006/geno.2000.6281

Arrieta, M. I., Criado, B., Hauspie, R., Martinez, B., Lobato, N., \& Lostao, C. M. 1992. Effects of genetic and environmental factors on the $\mathrm{a}-\mathrm{b}, \mathrm{b}-\mathrm{c}$ and $\mathrm{c}-\mathrm{d}$ interdigital ridge counts. Hereditas, 117(2), pp. 189-194. doi:10.1111/j.16015223.1992.tb00173.x

Ashbaugh, D. 1992. Defined pattern, overall pattern and unique pattern. Journal of Forensic Identification, 42 (6), pp. 503512.

Babler, W. J. 1991. Embryologic development of epidermal ridges and their configurations. Birth Defects Original Article Series, 27(2), pp. 95-112.

Bokhari, A., Coull, B. A., \& Holmes, L. B. 2002. Effect of prenatal exposure to anticonvulsant drugs on dermal ridge patterns of fingers. Teratology, 66(1), pp. 19-23. doi: $10.1002 /$ tera. 10044

Bouchard, T., Lykken, D., McGue, M., Segal, N., \& Tellegen, A. 1990. Sources of human psychological differences: the Minnesota Study of Twins Reared Apart. Science, 250(4978), pp. 223-228. doi:10.1126/science. 2218526

Chakraborty, R. 1991. The role of heredity and environment on dermatoglyphic traits. Birth Defects Original Article Series, 27(2), pp. 151-191.

Chatterjee, S. K., \& Mukherji, R. 1991. Genetics of epidermal ridges: a study in subjects with refractive errors. Journal of the Indian Medical Association, 89 (10), pp. 287-289.

Cummins, H., \& Midlo, C. 1976. Fingerprints, palms and soles.New York: Dover Publications Inc.

Farbrother, J. E., Kirov, G., Owen, M. J., \& Guggenheim, J. A. 2004. Family Aggregation of High Myopia: Estimation of the 
Sibling Recurrence Risk Ratio. Investigative Opthalmology and Visual Science, 45(9), p. 2873. doi:10.1167/iovs.03-1155

Froehlich, J. W., \& Giles, E. 1981. A multivariate approach to fingerprint variation in Papua New Guinea: Perspectives on the evolutionary stability of dermatoglyphic markers. American Journal of Physical Anthropology, 54(1), pp. 93-106. doi:10.1002/ajpa.1330540111

Galton, F. 2004. Finger prints: The classic 1892 Treatise.New York: Dover Publications Inc.

Gehring, W. J. 2002. The genetic control of eye development and its implications for the evolution of the various eyetypes. The International Journal of Developmental Biology, 46, pp. 65-73.

Gradiser, M., Matovinovic, O. M., Dilber, D., \& Bilic-Curcic, I. 2016. Assessment of Environmental and Hereditary Influence on Development of Pituitary Tumors Using Dermatoglyphic Traits and Their Potential as Screening Markers. International Journal of Environmental Research and Public Health, 13(3), p. 330. doi:10.3390/ijerph13030330

Guggenheim, J. A., Kirov, G., \& Hodson, S. A. 2000. The heritability of high myopia: a reanalysis of Goldschmidt's data. Journal of Medical Genetics, 37(3), pp. 227-231. doi:10.1136/jmg.37.3.227

Ho, Y. Y. W., Evans, D. M., Montgomery, G. W., Henders, A. K., Kemp, J. P., Timpson, N. J., . . . Davey-Smith, G. 2016. Common Genetic Variants Influence Whorls in Fingerprint Patterns. Journal of Investigative Dermatology, 136(4), pp. 859-862. doi:10.1016/j.jid.2015.10.062

Holden, B. A., Fricke, T. R., Wilson, D. A., Jong, M., Naidoo, K. S., Sankaridurg, P., . . . Resnikoff, S. 2016. Global Prevalence of Myopia and High Myopia and Temporal Trends from 2000 through 2050. Ophthalmology, 123(5), pp. 1036-1042. doi:10.1016/j.ophtha.2016.01.006

Holt, S. B. 1968. The genetics of dermal ridges.Springfield, Illinois: C. C. Thomas.

Ismail, E., Shairah, A. R., Selamat, L., Gurusamy, R., Zariman, H., Shahrudin, M. S., . . . Mohamad, O. 2009. Dermatoglyphics: comparison between Negritos Orang Asii and the malays, Chinese and Indian. Sains Malaysiana, 38 (6), pp. 947-952.

Karmakar, B., \& Kobyliansky, E. 2012. Finger and palmar dermatoglyphics in Muzeina Bedouins from South Sinai: qualitative traits. Papers on Anthropology, 20, p. 146. doi:10.12697/poa.2011.20.16

Kobyliansky, E., \& Micle, S. 1987. Dermatoglyphic sexual dimorphism in middle eastern Jews. Bulletins et memoires de la Soc d'Anthropologie de Paris, 14(4), pp. 271-290.

Li, J., \& Zhang, Q. 2017. Insight into the molecular genetics of myopia. Molecular Vision, 23, pp. 1048-1080.

Machado, J. F., Fernandes, P. R., Roquetti, R. W., \& Filho, J. F. 2010. Digital Dermatoglyphic Heritability Differences as Evidenced by a Female Twin Study. Twin Research and Human Genetics, 13(05), pp. 482-489. doi:10.1375/twin.13.5.482
Martín, B., Fañanás, L., Gutiérrez, B., Chow, E. W. C., \& Bassett, A. S. 2004. Dermatoglyphic profile in 22q deletion syndrome. American Journal of Medical Genetics Part B: Neuropsychiatric Genetics, 128B(1), pp. 46-49. doi:10.1002/ajmg.b.30034

Meier, R. J., Goodson, C. S., \& Roche, E. M. 1987. Dermatoglyphic development and timing of maturation. Human Biology, 59 (2), pp. 367-373.

Mittal, V. A., Dean, D. J., \& Pelletier, A. 2012. Dermatoglyphic asymmetries and fronto-striatal dysfunction in young adults reporting non-clinical psychosis. Acta Psychiatrica Scandinavica, 126(4), pp. 290-297. doi:10.1111/j.16000447.2012.01869.x

Naugler, C. T., \& Ludman, M. D. 1996. A case-control study of fluctuating dermatoglyphic asymmetry as a risk marker for developmental delay. American Journal of Medical Genetics, 66(1), pp. 11-14. doi:10.1002/(sici)10968628(19961202)66:1<11::aid-ajmg3>3.0.co;2-z

Nousbeck, J., Burger, B., Fuchs-Telem, D., Pavlovsky, M., Fenig, S., Sarig, O., . . . Sprecher, E. 2011. A Mutation in a Skin-Specific Isoform of SMARCAD1 Causes AutosomalDominant Adermatoglyphia. The American Journal of Human Genetics, 89(2), pp. 302-307. doi:10.1016/j.ajhg.2011.07.004

Reed, T., Viken, R. J., \& Rinehart, S. A. 2006. High heritability of fingertip arch patterns in twin-pairs. American Journal of Medical Genetics Part A, 140A(3), pp. 263-271. doi:10.1002/ajmg.a.31086

Sanfilippo, P. G., Hewitt, A. W., Hammond, C. J., \& Mackey, D. A. 2010. The Heritability of Ocular Traits. Survey of Ophthalmology, 55(6), pp. 561-583. doi:10.1016/j.survophthal.2010.07.003

Sirri, C. F., Gul, D., Tunca, Y., Fistik, T., Ozdemir, E. M., Yildiz, H., . . . Solak, M. 2008. Analysis of the dermatoglyphics in Turkish patients with Klinefelter's syndrome. Hereditas, 145(4), pp. 163-166. doi:10.1111/j.0018-0661.2008.02049.x

Stošljević, M., \& Adamović, M. 2013. Dermatoglyphic characteristics of digito-palmar complex in autistic boys in Serbia. Military Medical and Pharmaceutical Journal of Serbia, 70(4), pp. 386-390. doi:10.2298/vsp1304386s

Tang, W. C., Yap, M. K., \& Yip, S. P. 2008. A review of current approaches to identifying human genes involved in myopia. Clinical and Experimental Optometry, 91(1), pp. 422. doi:10.1111/j.1444-0938.2007.00181.x

Todd, E. S., Scott, N. M., Weese-Mayer, D. E., Weinberg, S. M., Berry-Kravis, E. M., Silvestri, J. M., . . . Marazita, M. L. 2006. Characterization of dermatoglyphics in PHOX2Bconfirmed central hypoventilation syndrome. Pediatrics, 118(2); e408-414.

Wertheim, K., \& Maceo, A. 2002. The critical stage of friction ridge and pattern formation. Journal of Forensic Identification, 52(1), pp. 35-85. 